\title{
Welcome to PathoGenetics
}

\section{Andrea Ballabio*1 and Stylianos Antonarakis²}

Address: ${ }^{1}$ Director Tigem, Telethon Institute of Genetics and Medicine, Napoli, Italy. and ${ }^{2}$ Department of Genetic Medicine and Development, University of Geneva Medical School, and University Hospitals of Geneva, Geneva, Switzerland.

Email: Andrea Ballabio* - ballabio@tigem.it; Stylianos Antonarakis - Stylianos.Antonarakis@medecine.unige.ch

* Corresponding author

Published: 3 November 2008

PathoGenetics 2008, I:I doi:10.1186/1755-8417-I-1

This article is available from: http://www.pathogenetics.com/content/I/I/I

(c) 2008 Ballabio et al; licensee BioMed Central Ltd.

This is an Open Access article distributed under the terms of the Creative Commons Attribution License (http://creativecommons.org/licenses/by/2.0), which permits unrestricted use, distribution, and reproduction in any medium, provided the original work is properly cited.
Received: 17 September 2008

Accepted: 3 November 2008

\begin{abstract}
Disease gene identification has made enormous strides in the past twenty years through functional, positional and candidate gene approaches, and more recently by the exploitation of genome-wide strategies. However, although pathogenic mutations in over 2000 genes have been identified as causative of human diseases, much less is known about the relationship between the molecular defects and mechanisms that lead to disease pathology and symptoms. Recent advances in diverse fields such as genomics, proteomics, cell biology, as well as studies on transgenic animals have greatly accelerated our understanding of the biochemical and cellular basis of many diseases but much still remains to be discovered. The current challenge is to understand the molecular and metabolic pathways by which a particular pathogenic variation leads to a specific phenotype. The study of abnormal conditions is of crucial importance for the understanding of normal physiology and often provides us with the rationale for the development of novel therapeutic strategies.
\end{abstract}

\section{Editorial}

PathoGenetics was created to meet the needs of the scientific community for a journal focused solely on the pathogenesis of genetic diseases. Currently studies on disease pathogenesis can be found in a variety of different journals with different scopes but none focuses entirely on the molecular and metabolic pathways perturbed in genetic diseases. PathoGenetics is a multidisciplinary journal which welcomes submissions from different approaches including cell biology, biochemistry, developmental and systems biology. Given its unique characteristics, PathoGenetics is likely to become the ideal journal for scientists from different backgrounds to publish and read exciting research on disease pathogenesis. PathoGenetics focuses on both in vitro and in vivo studies on the cascade of events leading from genomic lesions (i.e. either a gene mutation or a genomic rearrangement) to disease phenotypes. The discovery of novel molecular and metabolic pathways relevant to disease pathogenesis will be given specific emphasis.

The open access publishing model is the most effective way of ensuring that the research we publish can be accessed, read and built upon [1]. Once an article is accepted it is immediately published and deposited in PubMed ensuring dissemination of every article to a large audience independent of an access to a journal subscription and therefore directly benefiting the scientific community. There is evidence that an open access article is more likely to be used and cited than one subject to subscription barriers [2]. Manuscripts submitted to PathoGenetics will be peer-reviewed by at least two experts in the field after initial screening by the Editors-in-Chief and a consultation from the editorial board. We are delighted 
and proud that Pathogenetics has an outstanding editorial board [3], who will work with us to ensure the high quality of the research published in this new journal.

We are committed to making this journal a success and believe PathoGenetics will give scientists the unique opportunity to publish exciting research on the molecular mechanisms underlying the manifestation of disease phenotypes and provide a forum for the understanding of the biochemical and cellular mechanisms that underlie genetic disease. We would like to take this opportunity to welcoming you to this exciting new journal, and invite you to submit your important work to PathoGenetics.

\section{Competing interests}

The authors declare that they have no competing interests.

\section{References}

I. BioMed Central Open Access Charter [http://www.biomed central.com/info/about/charter]

2. Eysenbach G: Citation advantage of open access articles. PloS Biol 2006, 4(5):el57.

3. PathoGenetics Editorial Board [http://www.pathogeneticsjour nal.com/edboard/]

Publish with Bio Med Central and every scientist can read your work free of charge

"BioMed Central will be the most significant development for disseminating the results of biomedical research in our lifetime."

Sir Paul Nurse, Cancer Research UK

Your research papers will be:

- available free of charge to the entire biomedical community

- peer reviewed and published immediately upon acceptance

- cited in PubMed and archived on PubMed Central

- yours - you keep the copyright

Submit your manuscript here:

http://www.biomedcentral.com/info/publishing_adv.asp 